\title{
Overexpression of PCNA Attenuates Oxidative Stress-Caused Delay of Gap-Filling during Repair of UV-Induced DNA Damage
}

\author{
Yi-Chih Tsai, Yi-Hsiang Wang, and Yin-Chang Liu \\ Institute of Molecular Medicine, National Tsing Hua University, Hsinchu 30013, Taiwan \\ Correspondence should be addressed to Yin-Chang Liu; ycliu@life.nthu.edu.tw
}

Received 4 August 2016; Revised 12 October 2016; Accepted 15 November 2016; Published 1 January 2017

Academic Editor: Tapas Hazra

Copyright ( 2017 Yi-Chih Tsai et al. This is an open access article distributed under the Creative Commons Attribution License, which permits unrestricted use, distribution, and reproduction in any medium, provided the original work is properly cited.

\begin{abstract}
UVC irradiation-caused DNA lesions are repaired in mammalian cells solely by nucleotide excision repair (NER), which consists of sequential events including initial damage recognition, dual incision of damage site, gap-filling, and ligation. We have previously shown that gap-filling during the repair of UV-induced DNA lesions may be delayed by a subsequent treatment of oxidants or prooxidants such as hydrogen peroxide, flavonoids, and colcemid. We considered the delay as a result of competition for limiting protein/enzyme factor(s) during repair synthesis between NER and base excision repair (BER) induced by the oxidative chemicals. In this report, using colcemid as oxidative stress inducer, we showed that colcemid-caused delay of gap-filling during the repair of UV-induced DNA lesions was attenuated by overexpression of PCNA but not ligase-I. PCNA knockdown, as expected, delayed the gap-filling of NER but also impaired the repair of oxidative DNA damage. Fen-1 knockdown, however, did not affect the repair of oxidative DNA damage, suggesting repair of oxidative DNA damage is not of long patch BER. Furthermore, overexpression of XRCC1 delayed the gap-filling, and presumably increase of XRCC1 pulls PCNA away from gap-filling of NER for BER, consistent with our hypothesis that delay of gap-filling of NER attributes the competition between NER and BER.
\end{abstract}

\section{Introduction}

UVC irradiation or numerous carcinogenic chemicalscaused DNA adducts are repaired by nucleotide excision repair (NER). NER consists of a cascade of events including initial damage recognition, dual incision to excise the damage containing oligonucleotide, gap-filling, and ligation $[1,2]$. We have previously shown that oxidants such as hydrogen peroxide, menadione, and other chemicals including colcemid, amoxicillin, and flavonoids of propolis can inhibit gap-filling during the repair of UVC-induced DNA lesions [3]. For such study, the gap-filling was blocked by DNA synthesis inhibitors hydroxyurea and Ara-C $[4,5]$. Such blockage results in the accumulation of repair intermediates with the gap, which can be detected by methods such as single-cell gel electrophoresis, also called the comet assay $[6,7]$. If the DNA synthesis inhibitors are removed, the gap-filling will be quickly restored. Our previous studies indicate that the restoration of gap-filling can be delayed by oxidants or chemicals which have capacity to produce oxidative DNA damage
$[3,8]$. That type of damage can be detected by the comet assay with incubation of formamidopyrimidine glycosylase (Fpg) and endonuclease III (Endo III), which are bacterial enzymes that recognize oxidized purines and pyrimidines, respectively [9]. We have linked the repair of oxidative DNA damage, that is, base excision repair (BER), with the delay of gap-filling [3]. The delay is absent in BER deficient cells, for example, EM9 (in which XRCC1 is defective), and is restored if XRCC1 is supplemented. Moreover, while the gap-filling of NER is delayed by BER, repair of oxidative DNA adducts is not slowed down by NER, suggesting that the delay is probably not because of shortage of nucleotide precursors (dNTPs); if so, both NER and BER would have been affected. Rather, for some reason BER is dominant over NER.

Many types of DNA adducts including oxidative lesions are repaired by BER $[2,10]$. Like NER, BER consists of sequential steps including damage recognition and removal by glycosylase, strand cleave by AP lyase or AP endonuclease, $3^{\prime}$ or $5^{\prime}$ ends polishing, and gap-filling by either short patch (for 1 nucleotide) or long patch repair (for 2-15 nucleotides) 


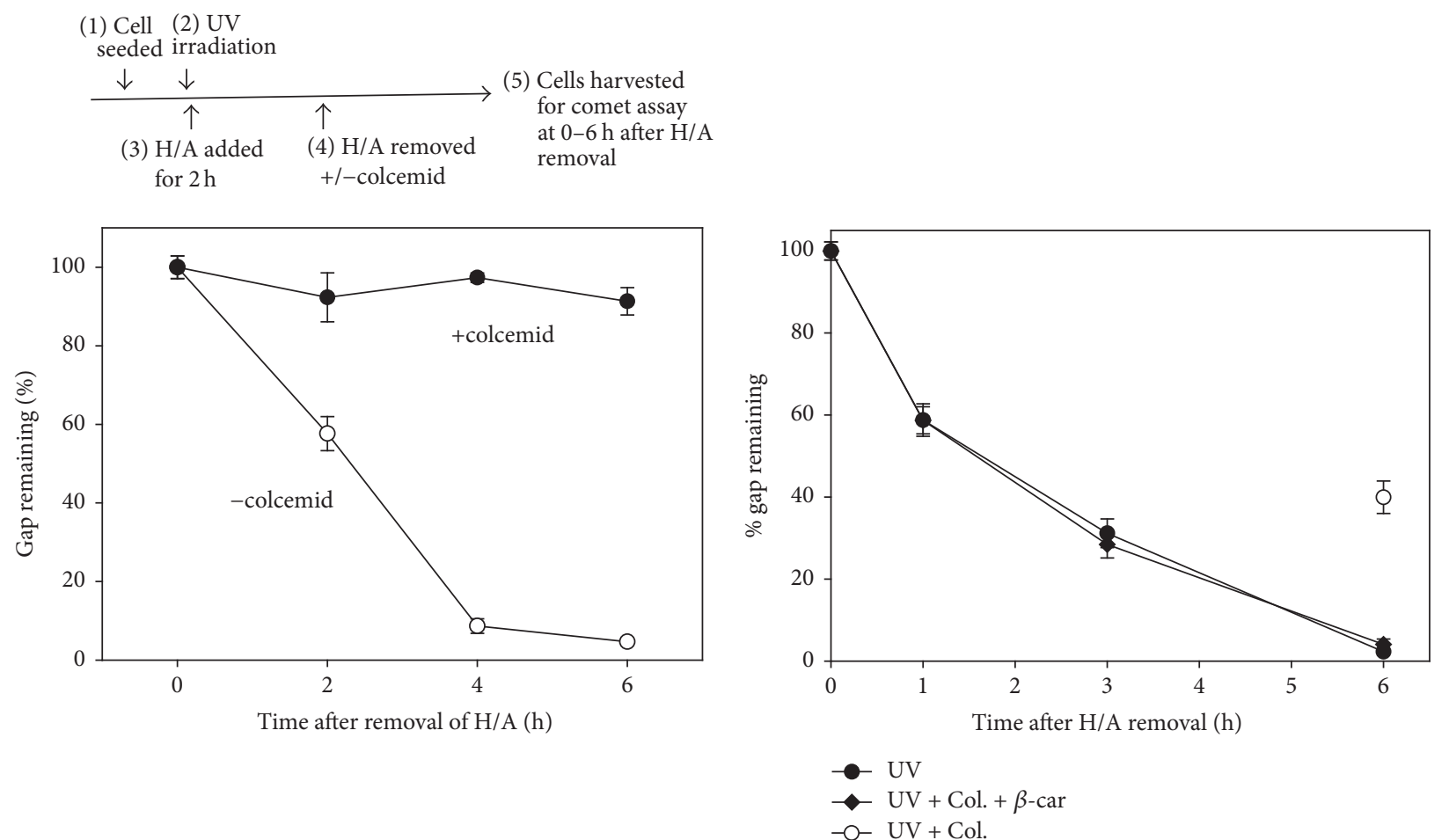

(a)

(b)

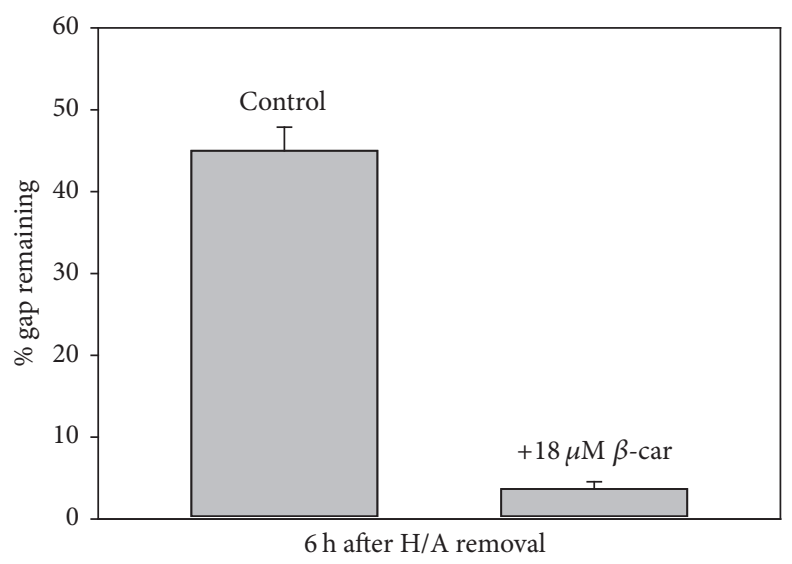

(c)

FIGURE 1: (a) Top: schematic illustration of experimental protocol for studying the effect of chemicals on gap-filling during repair of UVinduced DNA lesions. Bottom: colcemid delays the gap-filling. Initial level of the gaps at the time zero after H/A removal was taken as $100 \%$. (b) Similar to (a), AGS cells in log phase were UV irradiated $\left(3 \mathrm{~J} / \mathrm{m}^{2}\right)$ and $\mathrm{H} / \mathrm{A}$ treated for $2 \mathrm{~h}$. After H/A was removed, cells were treated with or without colcemid or $18 \mu \mathrm{M} \beta$-carotene. Cells were harvested for comet assay at the indicated time. (c) Similar to (b), cells were harvested at $6 \mathrm{~h}$ after H/A was removed for comet assay.

[11, 12]. For short patch repair, the gap is filled by DNA polymerase $\beta$ assisted by XRCC1 and Lig-III. For long patch repair, the gap is filled by DNA polymerase $\varepsilon / \delta$ assisted with PCNA, Fen-1, and (ligase-1) Lig-I. As the two excision repair mechanisms potentially share common machinery during gap-filling, we proposed that the delay is a consequence of competition for the limiting molecules (illustrated in Figure S1 in Supplementary Material available online at https://doi .org/10.1155/2017/8154646). PCNA, known as the sliding clamp of DNA polymerases [13], is involved in many aspects of DNA metabolism [14]. PCNA is essential to NER during gap-filling. Although involvement of PCNA in BER appears quite limited, numerous studies have indicated that PCNA interacts with almost all the players of BER including glycosylases, AP endonuclease, and XRCC1 [15-17].

Therefore, we consider PCNA the candidate of the limiting molecules linked with the delay. Besides, Lig-I and Fen-1 may be the limiting factors if repair of oxidative DNA damage 


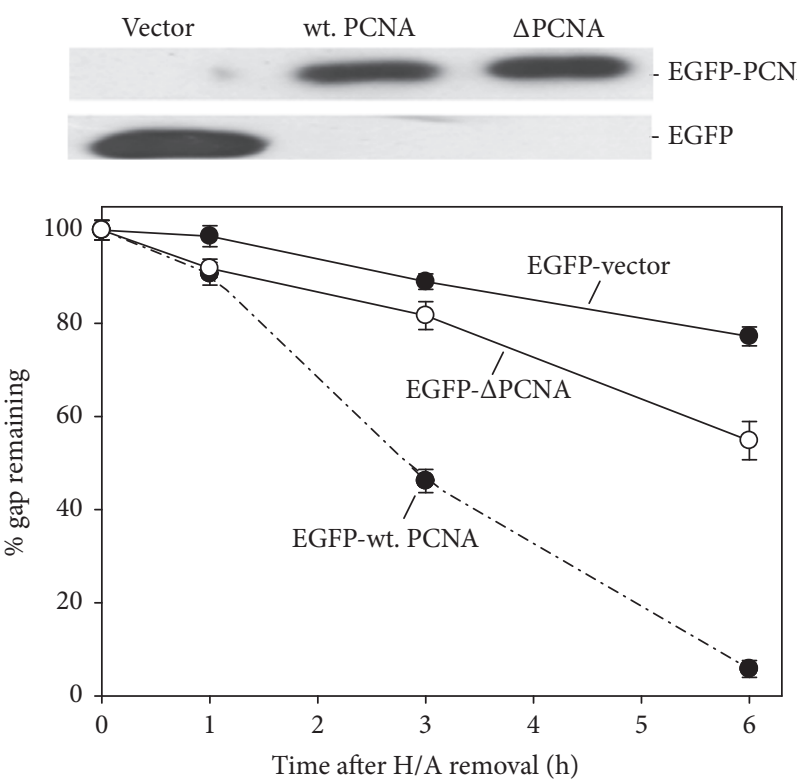

Figure 2: Top: western analysis of PCNA protein levels in total cell extracts of the CL1-0 cells stably transfected with wild type PCNA (EGFP-wt. PCNA) or truncated PCNA (EGFP- $\triangle$ PCNA) expression plasmids or EGFP-vector alone. Bottom: overexpression of PCNA attenuates colcemid-caused delay of gap-filling. CL1-0 cells stably transfected with the indicated plasmids were treated with the procedures illustrated in Figure 1 for studying the effect of PCNA overexpression on colcemid-caused delay of gap-filling during repair of UV-induced DNA lesions.

involves long patch pathway of BER. Results of our study indicate that overexpression of PCNA attenuates the delay. Similar effect was not found with overexpression of Lig-I. Furthermore, knockdown of Fen-1 did not impair the repair of oxidative stress-induced DNA damage. Thus, PCNA but not Lig-I or Fen-1 is required in repairing both UV and oxidative stresscaused DNA damage and becomes factors limiting for NER and BER, when these two kinds of DNA damage are induced at the same time.

Induction of both NER and BER simultaneously increased cell death compared to that of NER or BER alone. Overexpression of PCNA could reduce the cell death. Since overexpression of PCNA is prevalent in malignant tumors [18], our study provides insight from view of DNA repair that PCNA may be used as target of chemotherapy.

\section{Materials and Methods}

2.1. Cell Cultures, Expression Plasmids, and Antibodies and UV Irradiation. Human gastric adenocarcinoma AGS cells or human lung adenocarcinoma CL 1-0 cells were cultured in the conditions as those described previously [3]. Both cell lines were originally obtained from the American Type Culture Collection (Manassas, VA, USA). These two cell lines were used because of the availability and also the consideration of transfection: CL 1-0 cells appeared easier for obtaining stable transfectant compared to AGS cells. The expression plasmid of PCNA, pEGFP-N3-PCNA, was constructed with rat PCNA
cDNA [19] at the BamHI and EcoRI sites of the expression vector pEGFP-N3.

pEGFP-N3- $\triangle$ PCNA for PCNA without the C-terminal 39 amino acids was constructed from rat PCNA cDNA with polymerase chain reaction using the primers: forward GGGCGGCGTGAACCTACAG; reverse GCTCCCCACTCGCAGAAAACT. Lig-1 expression plasmid in pc1079pmRFP was obtained from H. Leonhardt (Ludwig Maximilians University). To knock down expression of PCNA or Fen1 the respective plasmids to produce short hairpin RNA of PCNA or Fen-1 in pLKO.1 were obtained from National RNAi Core Facility (Genomic Research Center, Taipei, Taiwan). Antibodies to monitor the protein levels of proteins including PCNA, Lig-1, and Fen-1 were provided by Santa Cruz Co. or GeneTex Co. Antibody of 8-oxo-dG was provided by Trevigen Co. (Gaithersburg, MD, USA). Cells were irradiated with a germicidal lamp (Sankyo Denki, Japan, $254 \mathrm{~nm}$ ). The fluorescence rate of the lamp was $50 \mathrm{~mW} / \mathrm{cm}^{2}$ calibrated with a UVX-254 radiometer (UVP Co., San Gabriel, CA, USA).

2.2. Chemicals. Most of chemicals including hydroxyurea, Ara-C, hydrogen, and peroxide were obtained from SigmaAldrich Co., while colcemid was obtained from Invitrogen Co. Most of the chemicals were dissolved in water before use. For studying the effect on gap-filling, cells at $60 \%$ confluence were UV irradiated $\left(10 \mathrm{~J} / \mathrm{m}^{2}\right)$ and were then treated with $2.5 \mathrm{mM}$ hydroxyurea and $25 \mu \mathrm{M}$ Ara-C (H/A) for $2 \mathrm{~h}$. Colcemid at $50 \mathrm{ng} / \mathrm{mL}$ would be used in this study for transient induction of oxidative DNA damage.

2.3. Comet Assay. Conventional comet assays (single-cell gel electrophoresis) were performed as described previously [20] with modifications [21]. Preparation of the cell-containing gel (on microscopic slides) and the subsequent cell lysis were carried out as described previously [21]. After cell lysis, the slides were washed three times with deionized water and were denatured in $0.3 \mathrm{~N} \mathrm{NaOH}$ and $1 \mathrm{mM}$ EDTA for $20 \mathrm{~min}$. Electrophoresis was carried out in the same denaturation solution at $25 \mathrm{~V}, 300 \mathrm{~mA}$ for $25 \mathrm{~min}$. Each slide was rinsed briefly in water, blotted, and then transferred to $0.4 \mathrm{M}$ Tris$\mathrm{HCl}, \mathrm{pH}$ 7.5. DNA was stained by adding $20 \mu \mathrm{L}$ propidium iodide $(50 \mu \mathrm{g} / \mathrm{mL})$ onto the slide. A coverslip was then applied, and the slide was examined using a Fluorescence Microscope (Axioplan 2, Zeiss Co.). Images of at least 50 cells per slide were recorded with a closed-circuit display camera (CoolSNAP). The migration of DNA from the nucleus of each cell was measured with a computer program (http://tritekcorp .com) and is expressed as \% DNA in the tail. Data are presented as averages of at least three independent experiments \pm standard error.

2.4. Comet Assay with Enzymes. To measure oxidative DNA adducts with the alkaline comet assay, we performed an additional step immediately after the cell lysis step, that is, incubating the slides containing the nucleoids with Endo III and Fpg (from Trevigen Co.; 2 units of each enzyme per slide in buffer with $10 \mathrm{mM}$ Tris- $\mathrm{HCl} \mathrm{pH}$ 7.4) as described previously [9]. Endo III and Fpg are bacterial glycosylases 

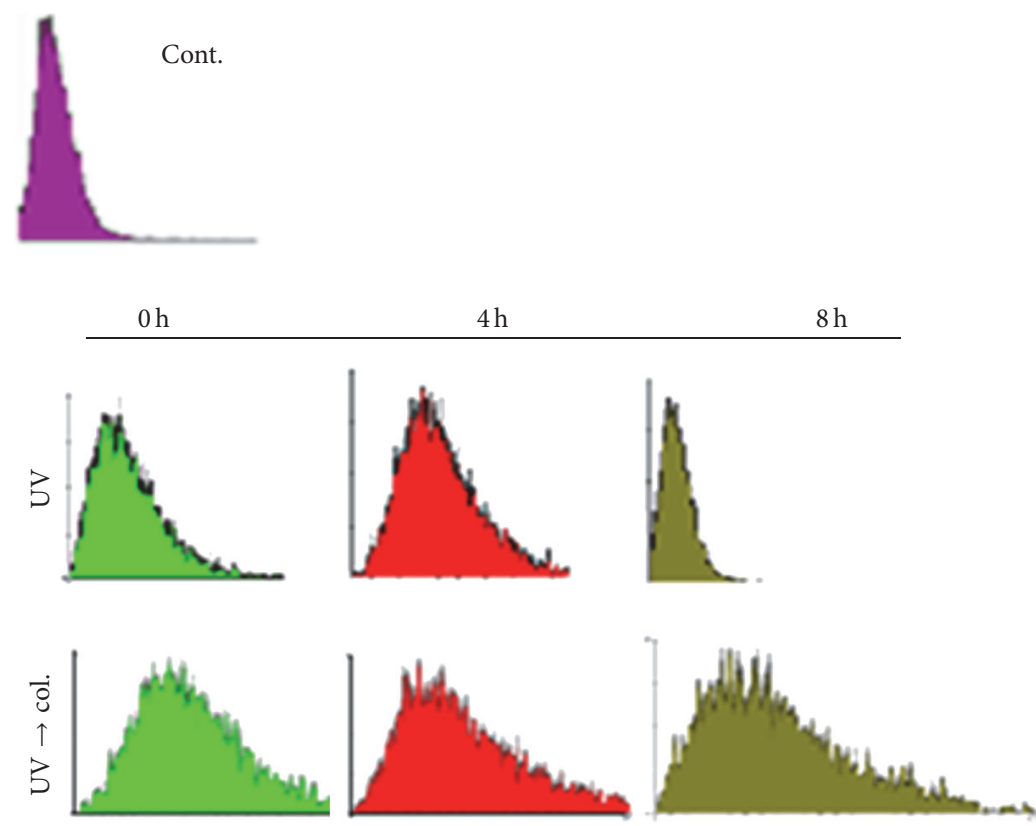

(a)
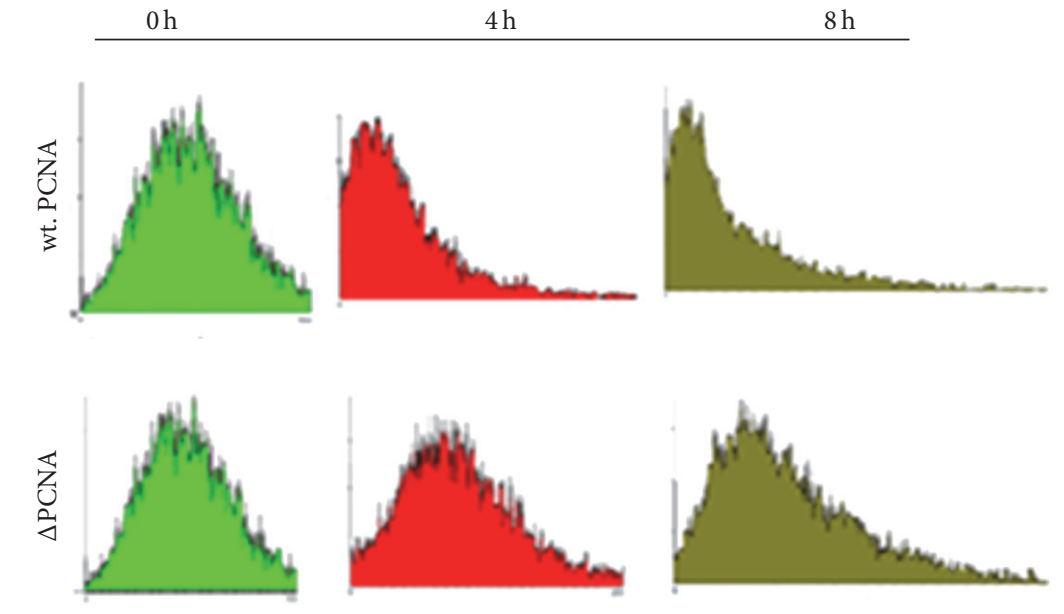

(b)

FIGURE 3: Flow cytometric analysis of nucleoid size. AGS cells were treated similarly as those described in Figure 1. (a) Cont. for control, that is, cells without treatment. UV and UV $\rightarrow$ col. for UV alone and UV then colcemid, respectively. Time points: $0-8 \mathrm{~h}$ after H/A removal. (b) Similar to (a), yet the cells were transiently transfected with the indicated expression plasmids. (Histogram: $x$-axis: forward scattering; $y$-axis: counts.)

that specifically recognize oxidized pyrimidines and purines, respectively.

2.5. Flow Cytometric Analysis of Nucleoid Size. This method is based on the phenomenon that nucleoid size becomes larger when cellular genome has damage. The original protocol [22] was used with modification. Immediately following lysis each sample was stained with propidium iodide (PI; $20 \mu \mathrm{g} / \mathrm{mL}$ ) and was analyzed in a Becton-Dickinson FACS 440 flow cytometer connected to an Apple microcomputer using peak height analog to digital conversion. Nucleoids were passed through a $594 \mathrm{~nm}$ argon laser beam at up to 150-300 nucleoids/s, and triggering on fluorescence, forward scatter, side scatter, and total PI fluorescence were collected. Some fluorescence nucleoid histograms were obtained using a Becton-Dickinson FACScan with analog to digital conversion carried out by area integration rather than peak height. The information is presented in the form of a frequency histogram.

2.6. ELISA of 8-OHdG. The method described previously [23] was followed with some modifications. In brief, cells were treated with $1 \mathrm{mM} \mathrm{H}_{2} \mathrm{O}_{2}$ for $1 \mathrm{~h}$ and harvested at the indicated time points for genomic DNA extraction. Each DNA sample was denatured at $95^{\circ} \mathrm{C}$ for $5 \mathrm{~min}$ and was then chilled on ice followed by incubation with 2 units of alkaline phosphatase 


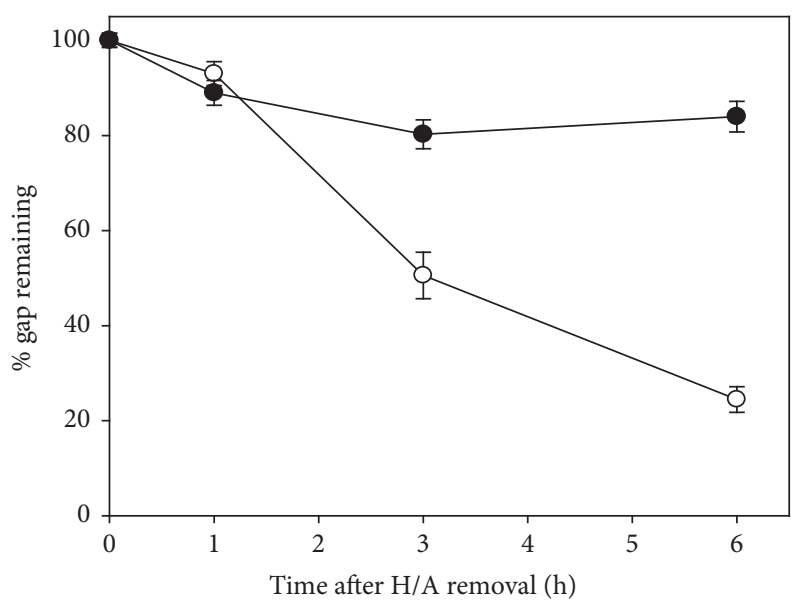

FIgURE 4: The effect of PCNA knockdown on gap-filling during repair of UV-induced DNA lesions. Similar to the procedures described in Figure 1, yet colcemid was excluded to avoid "overdelay." AGS cells were stably transfected with pLKO-1 shPCNA to knock down PCNA (closed circles) or control vector (open circles).

(BioLabs, Ipswich, MA, USA) and 5 units of DNase I (Sigma-

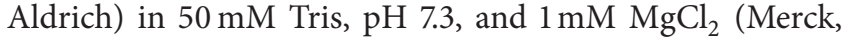
Germany) buffer at $37^{\circ} \mathrm{C}$ for $2 \mathrm{~h}$. 96-well plates were first coated with $0.003 \%$ protamine sulfate (Sigma-Aldrich) and then with $100 \mathrm{ng}$ 8-OHdG (Sigma-Aldrich). Coated wells were added in a series of concentrations of pure 8-OHdG or DNA samples. The antibody to 8-OHdG (1:500; Trevigen), biotin goat anti-mouse IgG (1:1000; Zymed Laboratories, Inc., San Francisco, CA, USA), and peroxidase-streptavidin (1:10000; Sigma-Aldrich) were used sequentially for the detection of 8-OHdG. O-Phenylenediamine (Pierce, Thermo Scientific, Rockford, IL, USA) dissolved in citrate phosphate buffer (5.103 g citrate acid monohydrate, $7.297 \mathrm{~g} \mathrm{Na}_{2} \mathrm{PO}_{4}$ in $1 \mathrm{~L} \mathrm{ddH_{2 }} \mathrm{O}$ adjusted to $\mathrm{pH} 5.0$ with citric acid) was used as a substrate for peroxidase. The absorbance was read at $492 \mathrm{~nm}$ with a microplate reader (Molecular Devices, Sunnyvale, CA, USA).

2.7. Immunostaining of 8-OHdG. The method described previously [24] was followed with some modifications. In brief, cells seeded for 1 day were treated with $1 \mathrm{mM} \mathrm{H}_{2} \mathrm{O}_{2}$ for $1 \mathrm{~h}$ and were harvested at the indicated time points for immunostaining. Cells after fixation were treated with $4 \mathrm{~N} \mathrm{HCl}$ to denature DNA. The antibody to 8 -OHdG $(1: 500)$ and a secondary antibody conjugated with Hilyte Flour 488 (1:200; Ana Spec Inc., Fremont, CA, USA) were used for detecting 8-OHdG. Nuclei were counterstained with 4',6-diamidino2-phenylindole (Sigma-Aldrich). Fluorescence images were captured by a digital camera on a Fluorescence Microscope (Zeiss/Axioskop 2 Mot plus).

2.8. Flow Cytometry Analysis of Cellular DNA Contents and the Measurement of BrdU Incorporation. The experiment was done based on the procedures described previously [25] In brief, human AGS cells were cultured with 5-bromo$2^{\prime}$-deoxyuridine (BrdU) (Sigma, USA) for $3 \mathrm{~h}$. After being washed with phosphate buffer saline (PBS), the cells were stored in $70 \% \mathrm{EtOH}$ at $-20^{\circ} \mathrm{C}$ overnight. Then, the cells were incubated in RNAse A (Sigma, USA) at $37^{\circ} \mathrm{C} 30 \mathrm{~min}$ to remove RNA. For denaturing DNA, the cells were treated with $\mathrm{HCl}$-Triton $(0.1 \mathrm{~N} \mathrm{HCl}+0.7 \%$ triton $\mathrm{X}-100)$ solution $10 \mathrm{~min}$ at ice and subsequently heated at $97^{\circ} \mathrm{C}$ in sterile water $2 \mathrm{~min}$ and put on ice for $15 \mathrm{~min}$. The cells were then incubated with 1:20 anti-BrdU (GTX, number 28039) solution at $37^{\circ} \mathrm{C}$ for $30 \mathrm{~min}$, then, reincubated with 1:20100 $\mathrm{mL}$ secondary antibody, mouse-FITC (GTX, number 85337), and washed with PBST (PBS + 5\% FBS + 0.5\% Tween 20). For DNA staining, the cells were resuspended in propidium iodide (PI) containing solution. The cell cycle profile and the BrdU incorporation were analyzed simultaneously by flow cytometry (FACS Calibur, Becton-Dickinson, Franklin Lakes, NJ).

\section{Results and Discussion}

Initially while studying the activity of tumor suppressor p53 in Chinese hamster ovary cell line $\mathrm{K} 1$, we noticed in serendipity that mitotic inhibitor, colcemid, caused a moderate increase of UV-induced cell death [26]. Further study indicates that colcemid though does not affect the excision of DNA adducts, it delays the gap-filling as shown in Figure 1. The intermediates of gap-filling were accumulated by the presence of hydroxyurea and Ara-C (H/A). Removal of $\mathrm{H} / \mathrm{A}$ resulted in quick decrease of $\%$ gap remaining (the open circles, Figure $1(\mathrm{a})$ ). The $\%$ gap remaining was calculated from the ratio between the level of DNA breaks detected at a certain time following H/A removal and the level of DNA breaks detected immediately before removal of H/A. Most of gaps remained unfilled in the presence of colcemid even at $6 \mathrm{~h}$ after H/A was removed (the closed circles, Figure 1(a)). Moreover, we found that not only colcemid but also amoxicillin and flavonoids of propolis showed similar inhibitory effect upon gap-filling. The commonality of these chemicals is their capacity to cause oxidative DNA damage (see Figure S2). Addition of antioxidant such as $\beta$-carotene abolished the colcemid-caused delay of gap-filling (Figure 1(b)): the rates of gap-filling between the treatment of UV alone and the treatment of UV plus colcemid and $\beta$-carotene were indistinguishable (Figure 1(b); compare the curve of closed circles and the curve of closed diamond). Also, as shown in Figure 1(c), while $>40 \%$ of gaps remained unfilled in the control experiment, most of the gaps were filled when $\beta$ carotene was added.

Thus, since the antioxidant was able to mitigate the effect of colcemid in gap-filling, the effect of colcemid in gap-filling is more likely attributed to its prooxidant capacity rather than its effect on mitotic spindles.

3.1. Overexpression of PCNA but Not Ligase-1 Attenuates the Delay of Gap-Filling. To know if PCNA is a limiting factor of gap-filling during NER in the presence of BER, we tested if overexpression of PCNA would attenuate the delay of gap-filling. For the study, the expression of PCNA in nuclei was examined by the immunostaining (Figure S3). Human CL 1-0 cells stably transfected with PCNA expressing or control plasmids were treated with UV irradiation, H/A, and 


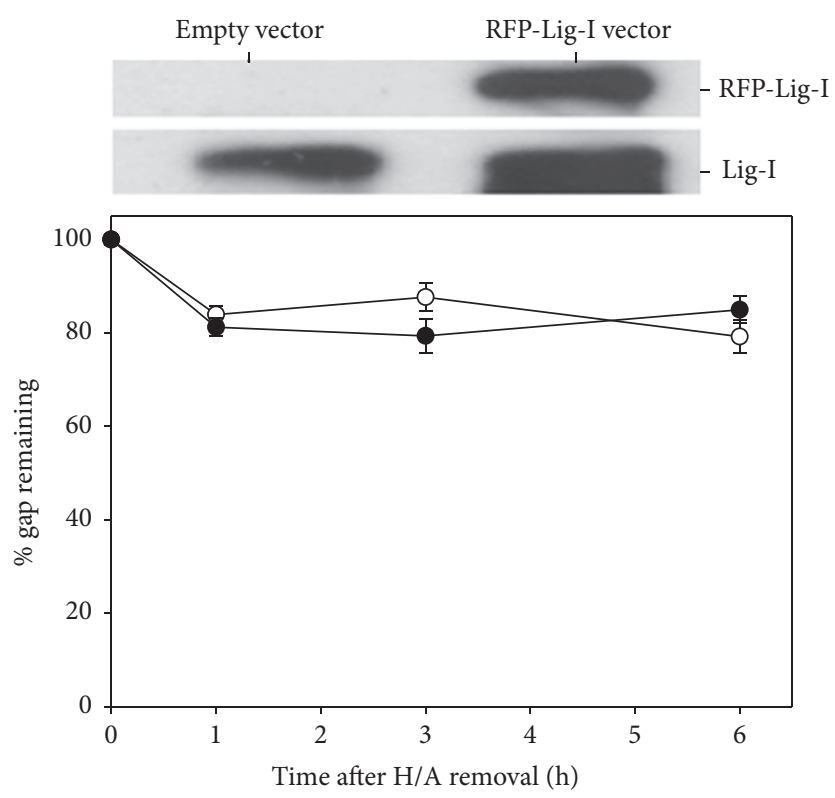

(a)
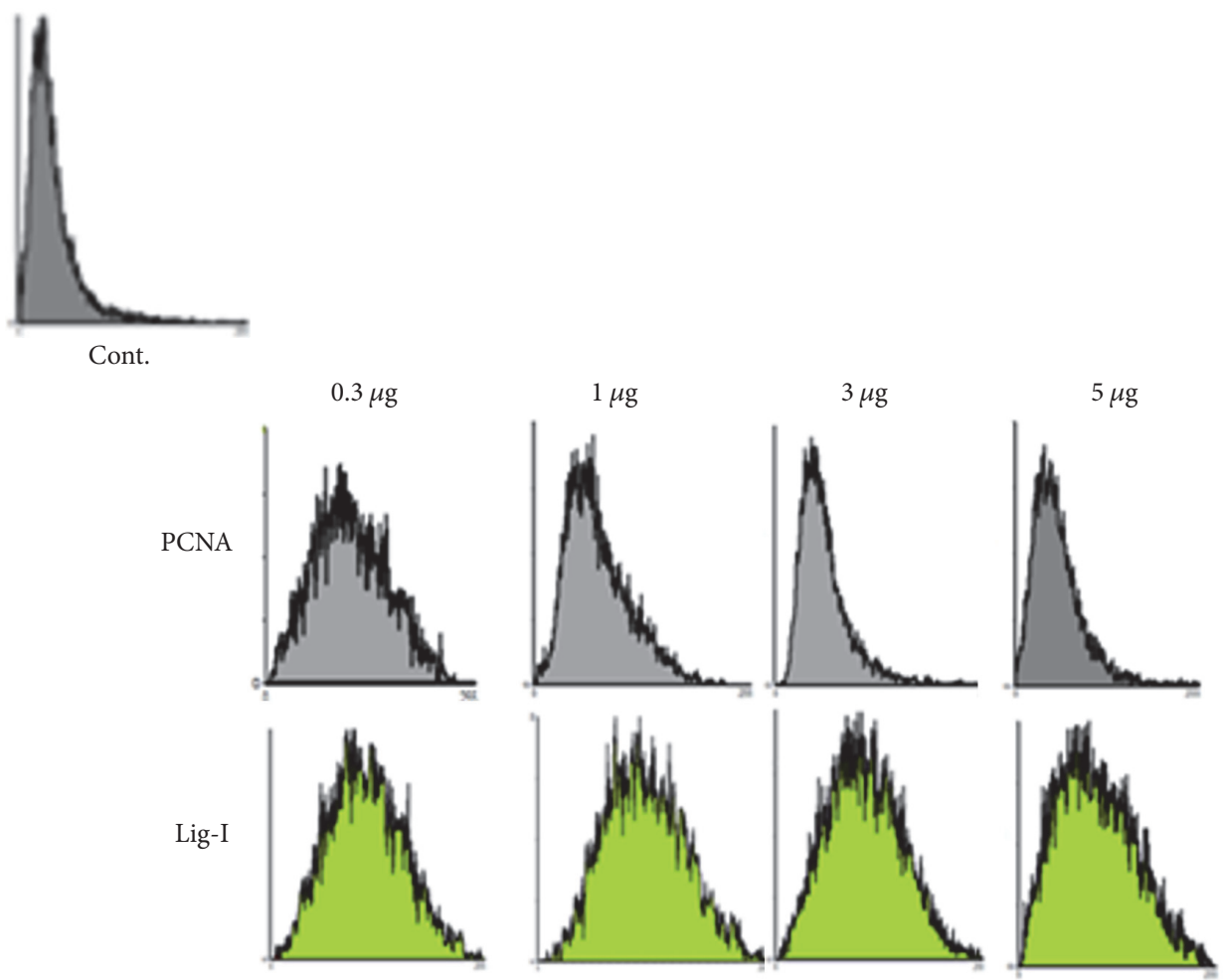

(b)

FIGURE 5: The effect of Lig-1 overexpression on colcemid-caused delay of gap-filling during repair of UV-induced DNA lesions. (a) Top: western analysis of Lig-1 protein in CL1-0 cells stably transfected with expression plasmid of Lig-1 (RFP-Lig-1) or empty vector. Bottom: similar to Figure 1, yet the CL1-0 cells stably transfected with expression plasmid of Lig-1 (filled circle) or empty vector (open circle) were used. (b) Flow cytometric analysis of nucleoid size. Dose dependence. Cells were transiently transfected with various amounts of PCNA or ligase-I expression plasmids. 

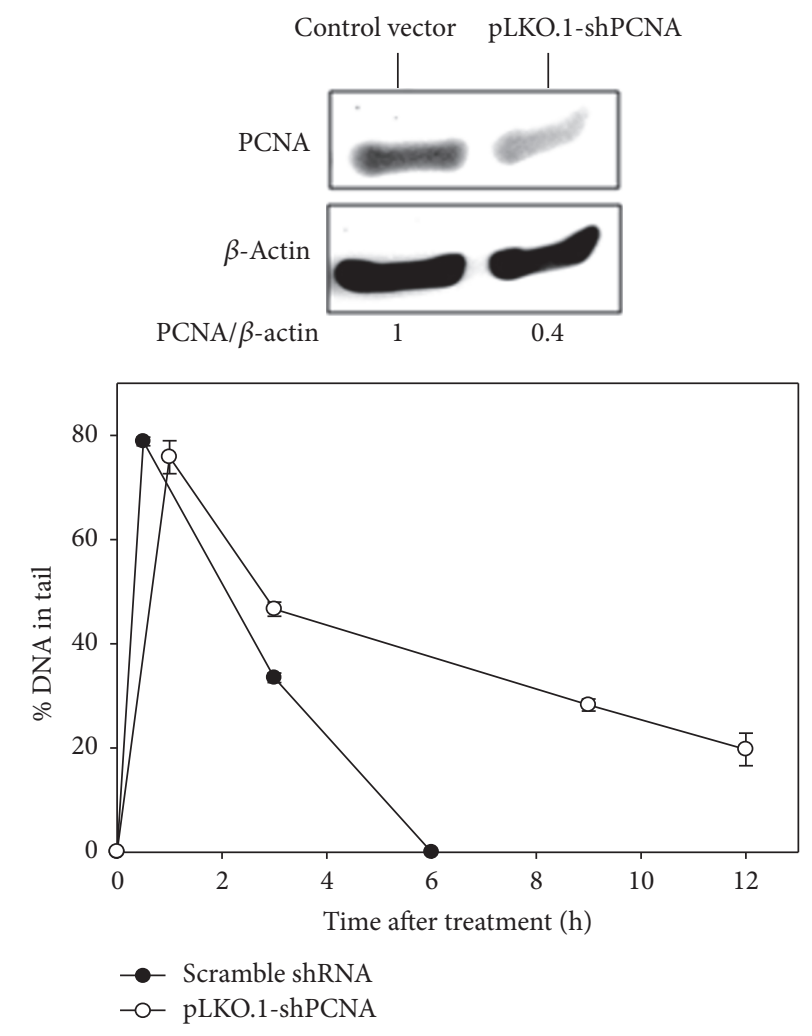

(a)

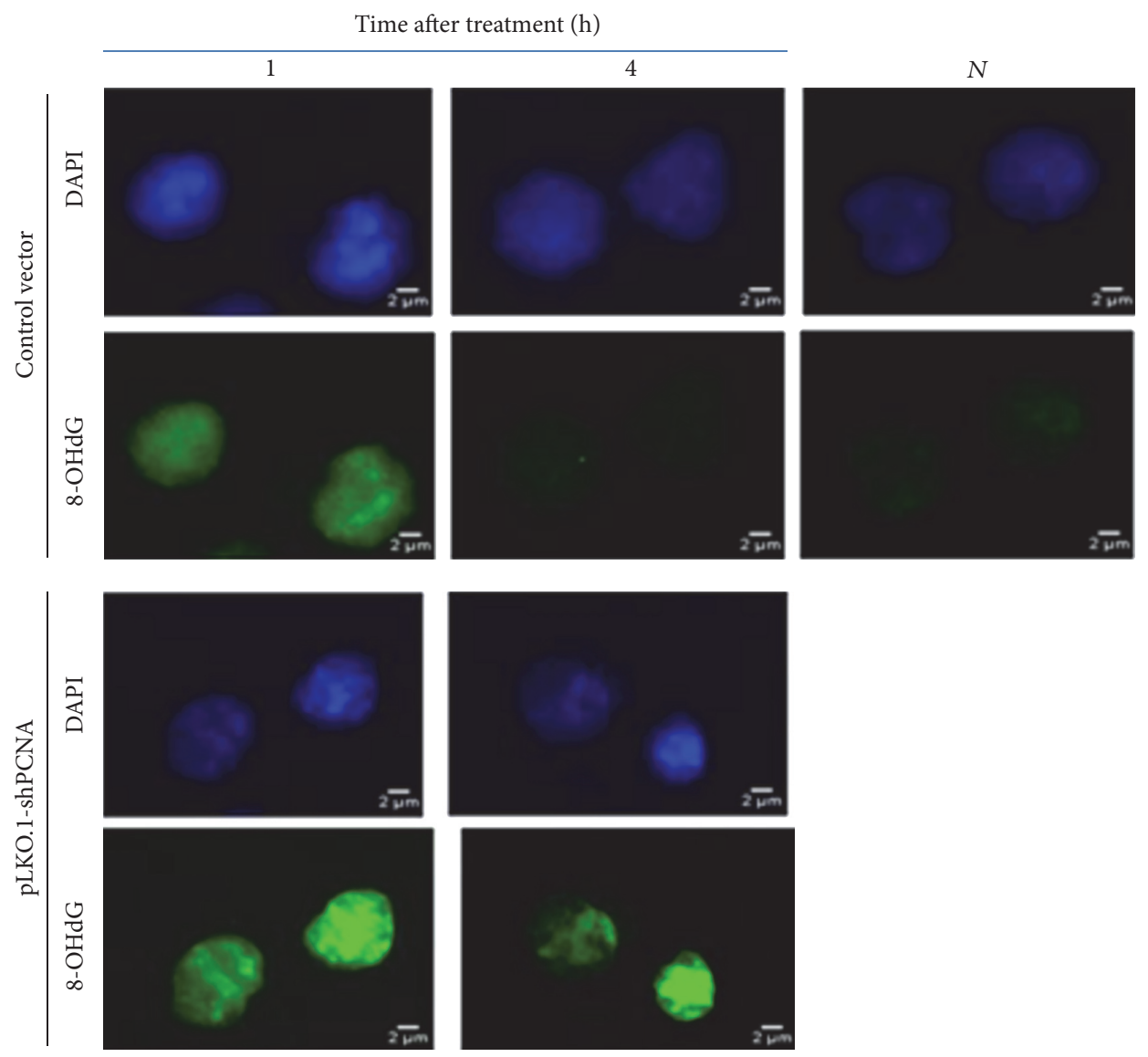

(b)

Figure 6: Continued. 


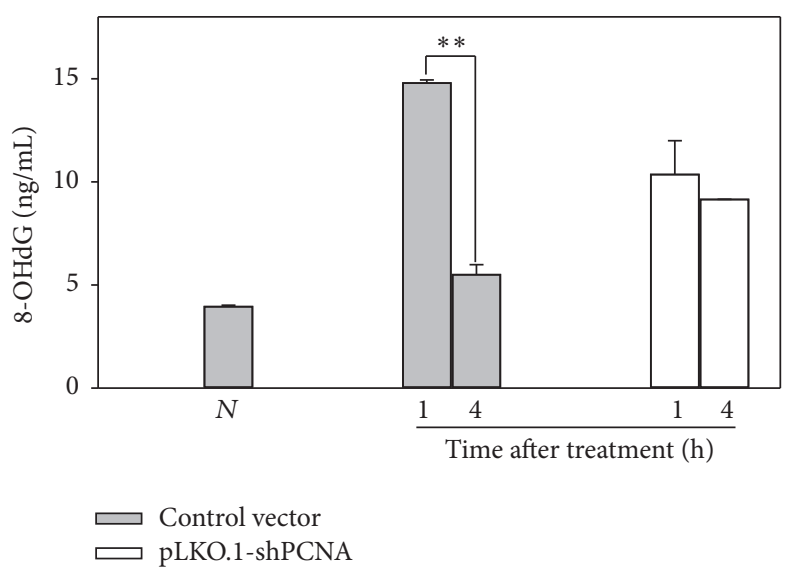

(c)

Figure 6: The effect of PCNA knockdown on the repair of oxidative DNA damage. (a) Comet assay. AGS cells transfected with pLKO-1 shPCNA to knock down PCNA or control vector were treated with $20 \mu \mathrm{M} \mathrm{H}_{2} \mathrm{O}_{2}$ for indicated periods of time before being harvested for comet-Fpg/Endo III assay to monitor the levels of $\mathrm{H}_{2} \mathrm{O}_{2}$-induced DNA lesions in cells. Bottom panel: western analysis of PCNA protein with levels of $\beta$-actin protein as a loading control. (b) Immunostaining analysis and (c) ELISA. Cells transfected with pLKO-1 shPCNA or control vector were treated with $1 \mathrm{mM} \mathrm{H}_{2} \mathrm{O}_{2}$ for 1 and $4 \mathrm{~h}$ before being harvested for immunofluorescence and ELISA assays of 8-oxo-dG. Typical images were shown. $N$ for control, that is, cells without treatment. $* *$ for $p<0.005$.

colcemid as described previously. Overexpression of PCNA in the form of EGFP fusion protein markedly reduced the delay of gap-filling, whereas EGFP alone had no similar effect (Figure 2). As compared to wild type PCNA, truncated form of PCNA ( $\triangle \mathrm{PCNA}$, with deletion of C-terminal 39 amino acids) showed much less effectiveness to attenuate the delay. C-terminal region of PCNA has been shown to be involved in interaction with ligase-1 or Fen-1 [27-29]. The attenuation effect of PCNA on the delay of gap-filling was also detected with the flow cytometry-based nucleoid size analysis. DNA strand breaks relax chromatin structure leading to increase of nucleoid size. If UV irradiation is done alone, nucleoid size is restored to control pattern at $8 \mathrm{~h}$ after H/A removal; presence of colcemid delayed the restoration (Figure 3(a)). Expression of wild type PCNA but not $\triangle \mathrm{PCNA}$ restored the nucleoid size to nearly the control pattern at $8 \mathrm{~h}$ after $\mathrm{H} / \mathrm{A}$ removal and in the presence of colcemid (Figure 3(b)). PCNA knockdown, in contrast, greatly delayed the gap-filling during repair of UV-induced DNA damage (Figure 4), encapsulating the necessity of PCNA to gap-filling of NER. Overexpression of ligase-I (Lig-1), however, failed to produce attenuation effect in comet assay (Figure 5(a)) and also in nucleoid size analysis regardless of the increase of Lig-1 expression vector (Figure 5(b)). Thus, Lig-1 may not be a limiting factor of gapfilling during NER in the presence of BER.

3.2. PCNA Is Essential to Repair of Oxidative Stress-Induced DNA Lesions. The above results indicate that PCNA is critical to gap-filling during repair of UV-induced DNA lesions. Increase of the abundance of PCNA facilitated gap-filling presumably because the level of the molecules was sufficient for both NER and BER. Although PCNA has been shown to be involved in long patch pathway of BER, it is unclear whether PCNA is essential for repairing the colcemid-induced oxidative DNA damage. To test if PCNA is necessary for repairing the oxidative stress-induced DNA damage, we examined the effect of PCNA knockdown on repair of Fpg/Endo III sensitive sites in $\mathrm{H}_{2} \mathrm{O}_{2}$-treated cells. PCNA knockdown greatly delayed the repair of oxidative stress-induced DNA lesions (Figure 6(a)). The effect of PCNA knockdown on BER was also confirmed with immunostaining and ELISA methods by monitoring the levels of 8-oxo-dG, a representative oxidized product of bases (Figures 6(b) and 6(c)).

3.3. The Repair of Oxidative Stress-Induced DNA Lesions Is Not Fen-1 Dependent. In contrast, knockdown of Fen1 , the endonuclease to remove flap structure during DNA replication, did not affect the repair of oxidative stressinduced DNA lesions (Figure 7(a)), though it reduced the fraction of S-phase as measured by BrdU incorporation (Figure $7(\mathrm{~b})$ ) as expected. Taking together, our data suggest that repair of oxidative stress-induced DNA damage may not be of long patch repair. It is of interest to know in our future study how PCNA is involved in repair of oxidative stressinduced DNA lesions. Our preliminary data indicate that repair of oxidative stress-induced DNA damage is PCNA and replication dependent (data not shown), consistent with the observation from biochemical study by other investigators that repair of oxidized bases is coupled with replication [16]. We speculate that PCNA may work together with XRCC1 to serve as scaffold for glycosylases/ligase in the situation.

3.4. Overexpression of XRCC1 Delayed the Gap-Filling. As mentioned earlier, XRCC1, also known as the scaffold protein of BER, interacts with PCNA [30]. To test whether XRCC1 recruits PCNA for repair of oxidative DNA damage, we examined if overexpression of XRCC1 impaired the gap-filling of NER. The experiment was done as those described in Figure 1: cells were UV irradiated and H/A were added for a period time to prevent gap-filling and then $\mathrm{H} / \mathrm{A}$ were removed 


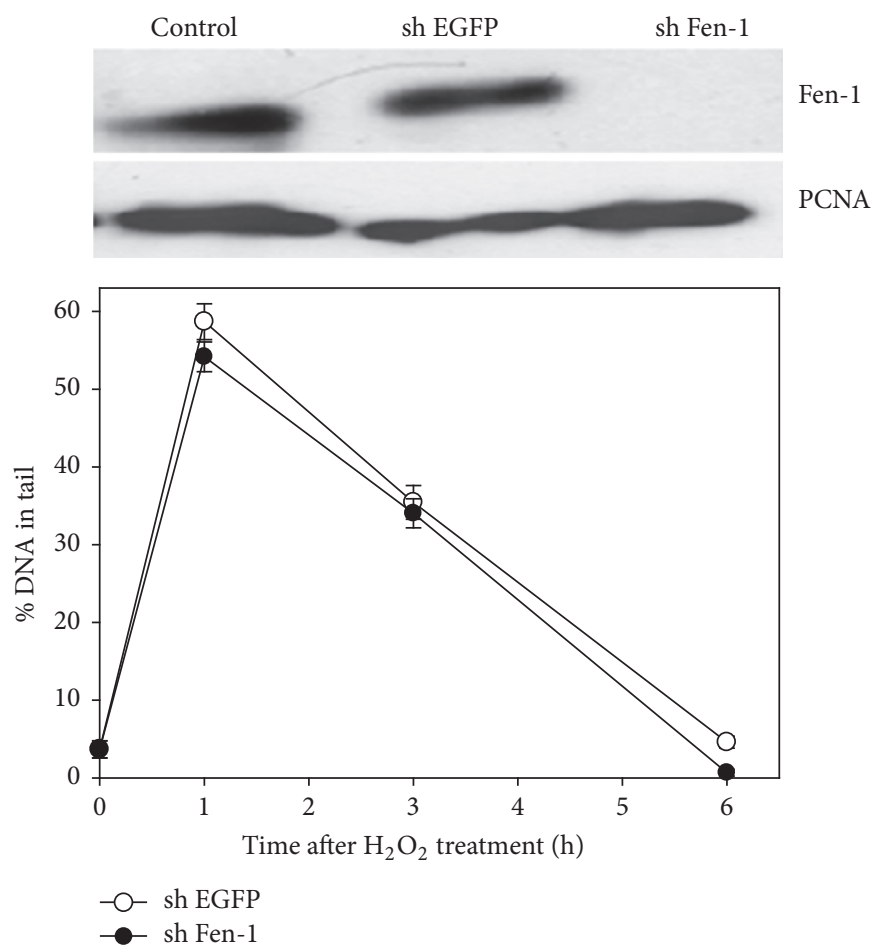

(a)
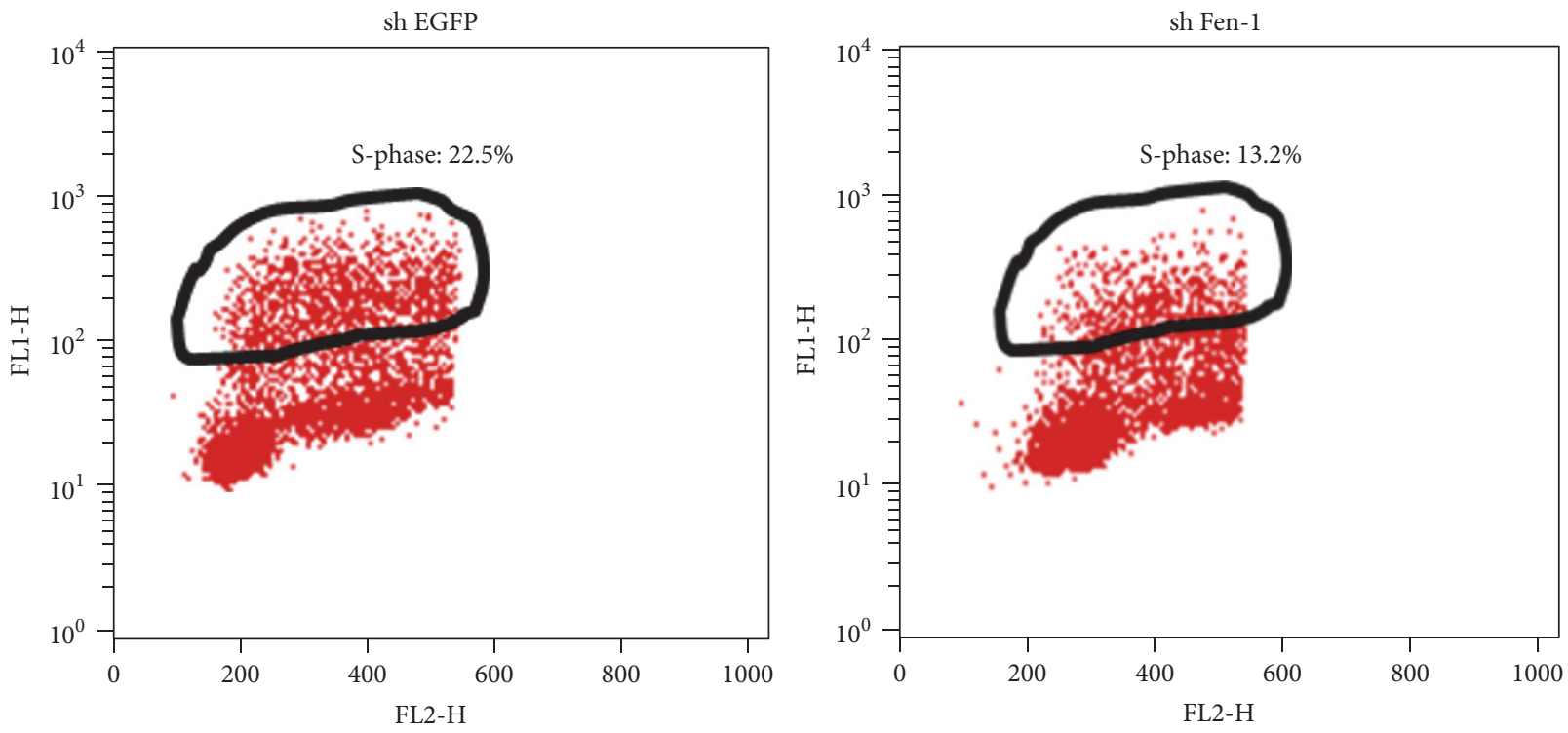

(b)

Figure 7: The effect of Fen-1 knockdown. (a) On repair of oxidative DNA damage. Top: western analysis of Fen-1 protein in AGS cells transfected with pLKO-1 sh Fen-1 to knock down Fen-1 or control vector; levels of PCNA protein were used as a loading control. Bottom: comet assay. AGS cells were treated with $20 \mu \mathrm{M} \mathrm{H}_{2} \mathrm{O}_{2}$ for indicated periods of time before being harvested for comet-Fpg/Endo III assay. (b) On DNA replication. S-phase cells were marked.

to allow gap-filling to take place. The results indicate that overexpression of XRCC1 delayed the gap-filling. With overexpression of XRCC1, the remaining of gaps was about $60 \%$, while the control had only about $10 \%$ at $6 \mathrm{~h}$ after removal of H/A (Figure 8(a)). Since the experiment was done with cells without oxidative stress inducer such as colcemid, the result suggests the preferential repair of BER for endogenous level of oxidized bases over NER when XRCC1 was overexpressed. Thus, the level of XRCC1 in ordinary cells must be regulated to avoid the delay of gap-filling of NER. Furthermore, the results (Figure $8(\mathrm{a})$ ) were verified by the flow cytometric analysis of nucleoid size (Figure 8(b)). Consistently, the overexpression of XRCC1 compromised the overexpression of PCNA (Figure 8(c)). The rate of gap-filling in cells transfected 


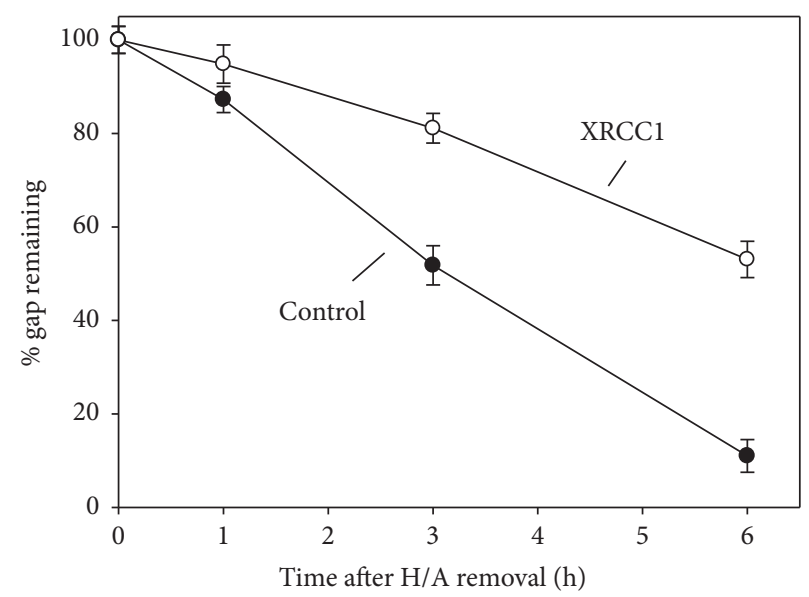

(a)
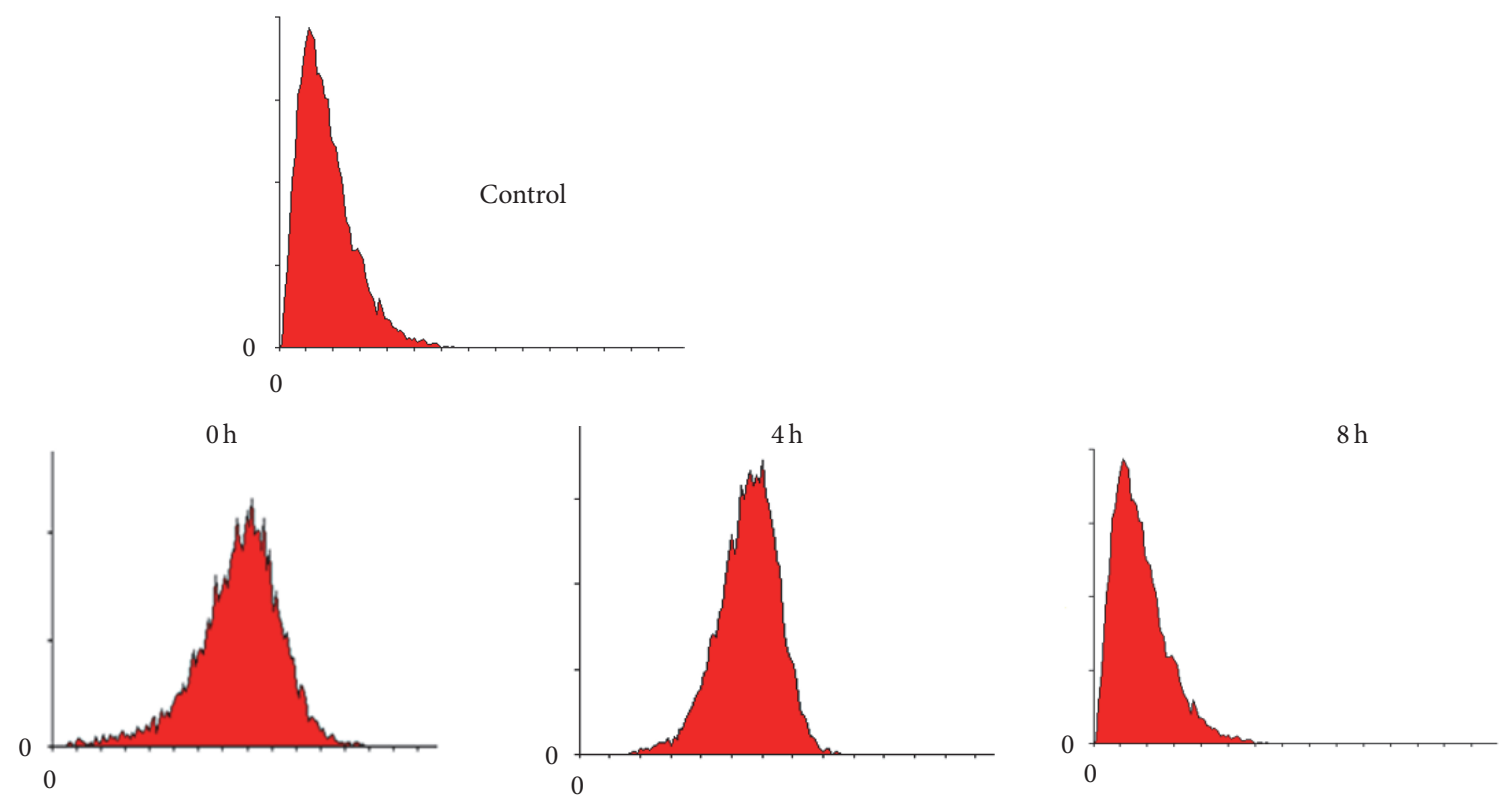

Empty vector
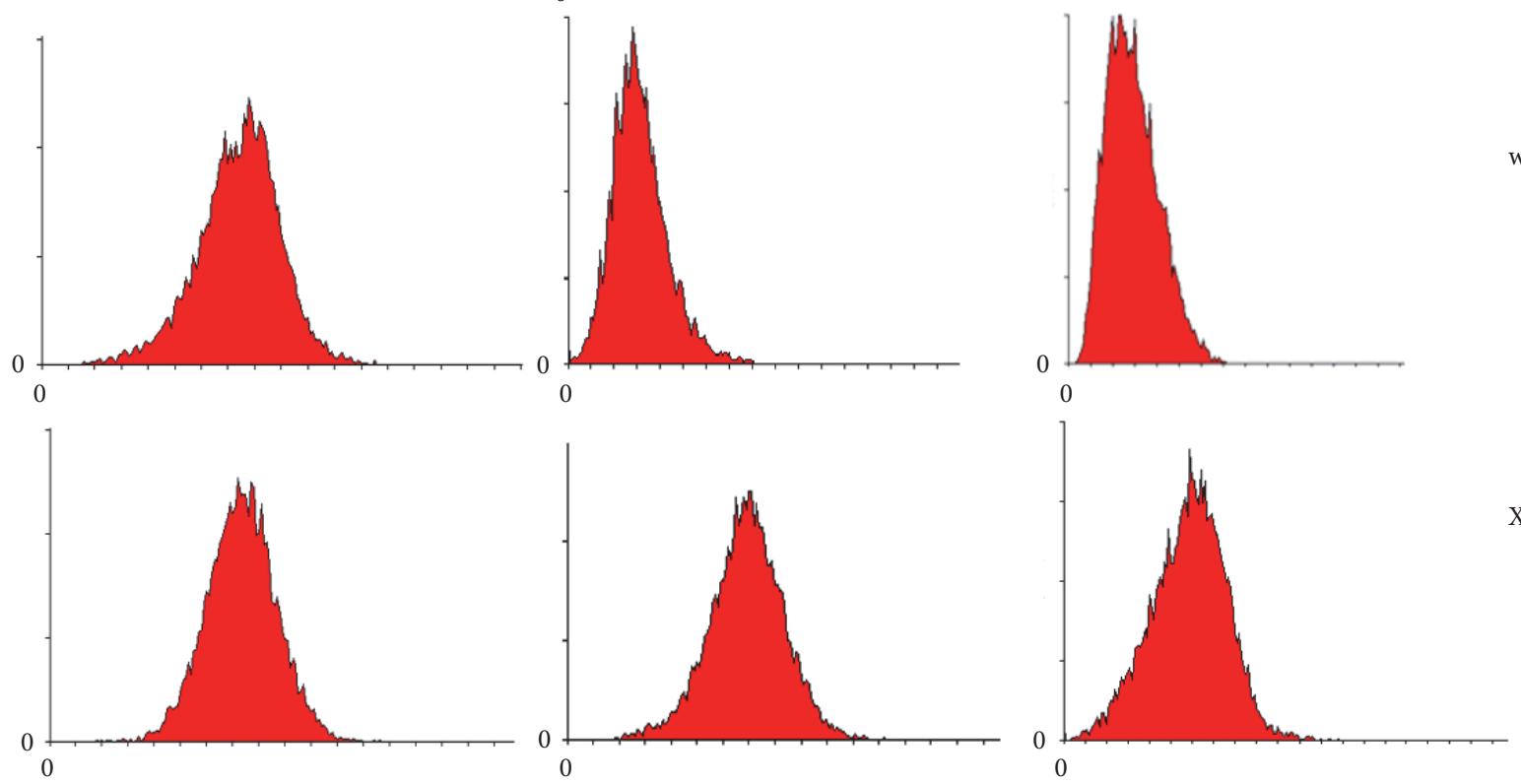

(b)

FIgURE 8: Continued. 


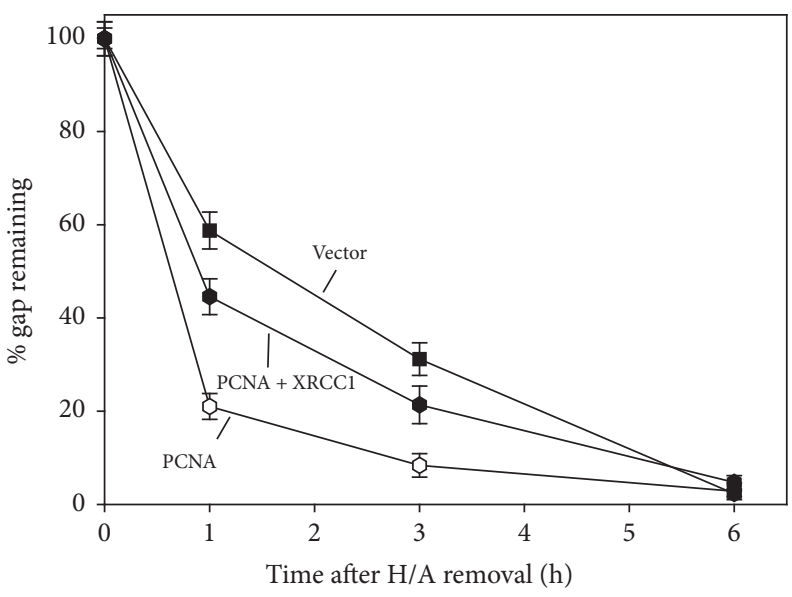

(c)

FIGURE 8: The effect of XRCC1 overexpressed on the gap-filling during repair of UV-induced DNA lesions. ((a) and (b)) Similar to the procedures described in Figures 1 and 3, yet colcemid was excluded. (a) AGS cells were transiently transfected with pCMV XRCC1 plasmids (open circle) or not (closed circle). (b) Cont. for control, that is, cells without treatment. AGS cells were transfected with wt. PCNA or pCMVXRCC1 or empty vector. Time points: $0-8 \mathrm{~h}$ after H/A removal. Histograms of both panels: $x$-axis: forward scattering (relevant to particle size); $y$-axis: cell counts. (c) Similar to procedures described in Figure 1, colcemid was present, and AGS cells transfected with empty vector or plasmid EGF-PCNA with or without pCMV XRCC1 were used.

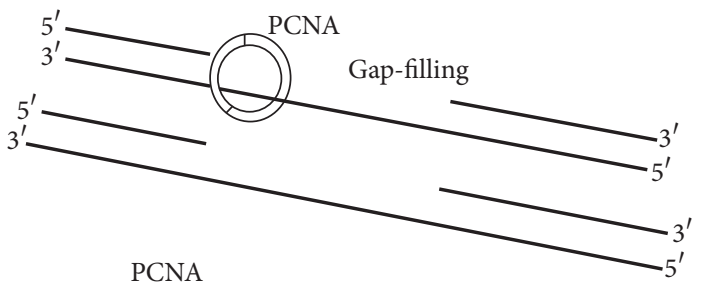<smiles>C1=C=C=C=C=C=C=C=C=C=C=C=C=1</smiles><smiles>C1=CC=CCC=C1</smiles>
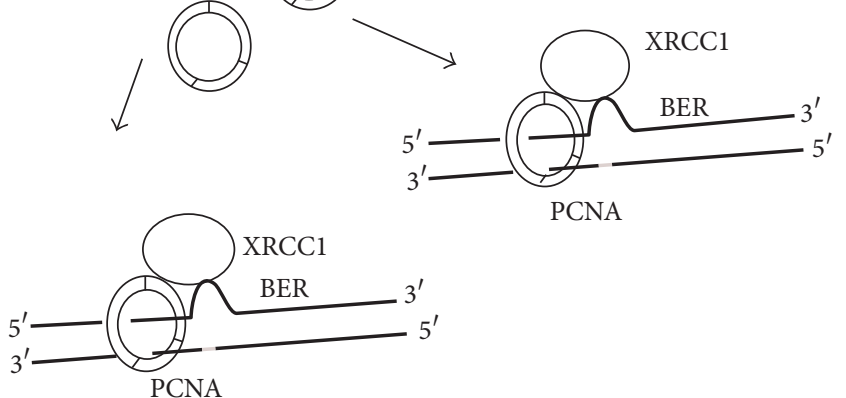

FIGURE 9: PCNA is important to the gap-filling during the repair of UV-induced DNA injuries and is also essential to the repair of oxidative DNA lesions. When oxidative DNA damage increases or XRCC1 overexpresses, more PCNA is recruited to BER, which may leave more gaps unfilled.

with PCNA and XRCC1 was slower than with PCNA alone (Figure 8(c), compare the curve of closed circles and the curve of open circles). Thus, increase of XRCC1 inhibits the gap-filling, and presumably XRCC1 pulls PCNA away from NER for BER. This experiment supports our hypothesis that competition for common components such as PCNA between NER and BER can cause delay of gap-filling of NER.

Our observations suggest that PCNA is essential to both NER and BER and becomes limited when excision repairs function. Gap-filling of NER is forced to stand by until BER is completed. Overexpression of PCNA may lift the stringency (Figure 9).

Delay of gap-filling of NER might cause a modest increase of cell death, which could be suppressed by overexpression of PCNA (Supplementary Figure S4). Thus, it is likely that cells may increase expression of PCNA to overcome the trauma. In fact, elevation of PCNA is commonly detected in malignant tumors (e.g., reviewed by [18]). Recently, small molecule inhibitors of PCNA or peptides targeting PCNA have been developed and appear promising for cancer therapy [31,32].

\section{Competing Interests}

The authors declare that there is no conflict of interests regarding the publication of this paper.

\section{References}

[1] J. De Boer and J. H. J. Hoeijmakers, "Nucleotide excision repair and human syndromes," Carcinogenesis, vol. 21, no. 3, pp. 453460, 2000.

[2] E. C. Friedberg, DNA Repair and Mutagenesis, ASM Press, Washington, DC, USA, 2nd edition, 2006.

[3] M.-K. Chen, Y.-C. Tsai, P.-Y. Li et al., "Delay of gap filling during nucleotide excision repair by base excision repair: the concept of competition exemplified by the effect of propolis," Toxicological Sciences, vol. 122, no. 2, pp. 339-348, 2011. 
[4] A. R. S. Collins, S. L. Schor, and R. T. Johnson, "The inhibition of repair in UV irradiated human cells," Mutation Research, vol. 42, no. 3, pp. 413-432, 1977.

[5] Y. Fujiwara, "Postreplication repair of ultraviolet damage to DNA, DNA chain elongation, and effects of metabolic inhibitors in mouse L cells," Biophysical Journal, vol. 15, no. 5, pp. 403-415, 1975.

[6] C. M. Gedik, S. W. B. Ewen, and A. R. Collins, "Single-cell gel electrophoresis applied to the analysis of UV-c damage and its repair in human cells," International Journal of Radiation Biology, vol. 62, no. 3, pp. 313-320, 1992.

[7] S. Lynn, H.-T. Lai, J.-R. Gurr, and K. Y. Jan, "Arsenite retards DNA break rejoining by inhibiting DNA ligation," Mutagenesis, vol. 12, no. 5, pp. 353-358, 1997.

[8] P.-Y. Li, Y.-C. Chang, B.-S. Tzang, C.-C. Chen, and Y.-C. Liu, "Antibiotic amoxicillin induces DNA lesions in mammalian cells possibly via the reactive oxygen species," Mutation Research/Genetic Toxicology and Environmental Mutagenesis, vol. 629, no. 2, pp. 133-139, 2007.

[9] A. R. Collins, "The comet assay for DNA damage and repair: principles, applications, and limitations," Applied Biochemistry and Biotechnology -Part B Molecular Biotechnology, vol. 26, no. 3, pp. 249-261, 2004.

[10] T. K. Hazra, A. Das, S. Das, S. Choudhury, Y. W. Kow, and R. Roy, "Oxidative DNA damage repair in mammalian cells: a new perspective," DNA Repair, vol. 6, no. 4, pp. 470-480, 2007.

[11] P. Fortini, B. Pascucci, E. Parlanti, M. D’Errico, V. Simonelli, and E. Dogliotti, "The base excision repair: mechanisms and its relevance for cancer susceptibility," Biochimie, vol. 85, no. 11, pp. 1053-1071, 2003.

[12] A. B. Robertson, A. Klungland, T. Rognes, and I. Leiros, "DNA repair in mammalian cells: base excision repair: the long and short of it," Cellular and Molecular Life Sciences, vol. 66, no. 6, pp. 981-993, 2009.

[13] J. Kuriyan and M. O’Donnell, "Sliding clamps of DNA polymerases," Journal of Molecular Biology, vol. 234, no. 4, pp. 915925, 1993.

[14] I. Stoimenov and T. Helleday, "PCNA on the crossroad of cancer," Biochemical Society Transactions, vol. 37, no. 3, pp. 605613, 2009.

[15] P. Burkovics, I. Hajdú, V. Szukacsov, I. Unk, and L. Haracska, "Role of PCNA-dependent stimulation of 3 ' -phosphodiesterase and $3^{\prime}-5^{\prime}$ exonuclease activities of human Ape2 in repair of oxidative DNA damage," Nucleic Acids Research, vol. 37, no. 13, pp. 4247-4255, 2009.

[16] H. Dou, C. A. Theriot, A. Das et al., "Interaction of the human DNA glycosylase NEIL1 with proliferating cell nuclear antigen: the potential for replication-associated repair of oxidized bases in mammalian genomes," Journal of Biological Chemistry, vol. 283, no. 6, pp. 3130-3140, 2008.

[17] S. N. Naryzhny, "Proliferating cell nuclear antigen: a proteomics view," Cellular and Molecular Life Sciences, vol. 65, no. 23, pp. 3789-3808, 2008.

[18] A. D. Giglio, S. O’brien, R. J. Ford et al., "Proliferating cell nuclear antigen (PCNA) expression in chronic lymphocytic leukemia (CLL)," Leukemia and Lymphoma, vol. 10, no. 4-5, pp. 265-271, 1993.

[19] Y.-C. Liu, R. L. Marraccino, P. C. Keng et al., "Requirement for proliferating cell nuclear antigen expression during stages of the Chinese hamster ovary cell cycle," Biochemistry, vol. 28, no. 7, pp. 2967-2974, 1989.
[20] N. P. Singh, M. T. McCoy, R. R. Tice, and E. L. Schneider, "A simple technique for quantitation of low levels of DNA damage in individual cells," Experimental Cell Research, vol. 175, no. 1, pp. 184-191, 1988.

[21] Y.-C. Chang, K.-Y. Jan, C.-A. Cheng, C.-B. Liao, and Y.-C. Liu, "Direct involvement of the tumor suppressor p53 in nucleotide excision repair," DNA Repair, vol. 7, no. 5, pp. 751-761, 2008.

[22] D. J. Gordon, A. E. Milner, R. P. Beaney, D. J. Grdina, and A. T. M. Vaughan, "The increase in radioresistance of Chinese hamster cells cultured as spheroids is correlated to changes in nuclear morphology," Radiation Research, vol. 121, no. 2, pp. 175179, 1990.

[23] S. Inturi, N. Tewari-Singh, M. Gu et al., "Mechanisms of sulfur mustard analog 2-chloroethyl ethyl sulfide-induced DNA damage in skin epidermal cells and fibroblasts," Free Radical Biology and Medicine, vol. 51, no. 12, pp. 2272-2280, 2011.

[24] R. P. Soultanakis, R. J. Melamede, I. A. Bespalov et al., "Fluorescence detection of 8-oxoguanine in nuclear and mitochondrial DNA of cultured cells using a recombinant Fab and confocal scanning laser microscopy," Free Radical Biology \& Medicine, vol. 28, no. 6, pp. 987-998, 2000.

[25] C. A. Hoy, L. C. Seamer, and R. T. Schimke, "Thermal denaturation of DNA for immunochemical staining of incorporated bromodeoxyuridine (BrdUrd): critical factors that affect the amount of fluorescence and the shape of BrdUrd/DNA histogram," Cytometry, vol. 10, no. 6, pp. 718-725, 1989.

[26] H. Li, T.-W. Chang, Y.-C. Tsai et al., "Colcemid inhibits the rejoining of the nucleotide excision repair of UVC-induced DNA damages in Chinese hamster ovary cells," Mutation Research, vol. 588, no. 2, pp. 118-128, 2005.

[27] B. R. Chapados, D. J. Hosfield, S. Han et al., "Structural Basis for FEN-1 Substrate Specificity and PCNA-Mediated Activation in DNA Replication and Repair," Cell, vol. 116, no. 1, pp. 39-50, 2004.

[28] X. V. Gomes and P. M. J. Burgers, “Two modes of FEN1 binding to PCNA regulated by DNA," The EMBO Journal, vol. 19, no. 14, pp. 3811-3821, 2000.

[29] S. Vijayakumar, B. R. Chapados, K. H. Schmidt, R. D. Kolodner, J. A. Tainer, and A. E. Tomkinson, "The C-terminal domain of yeast PCNA is required for physical and functional interactions with Cdc9 DNA ligase," Nucleic Acids Research, vol. 35, no. 5, pp. 1624-1637, 2007.

[30] J. Fan, M. Otterlei, H.-K. Wong, A. E. Tomkinson, and D. M. Wilson III, "XRCC1 co-localizes and physically interacts with PCNA," Nucleic Acids Research, vol. 32, no. 7, pp. 2193-2201, 2004.

[31] Z. Tan, M. Wortman, K. L. Dillehay et al., "Small-molecule targeting of proliferating cell nuclear antigen chromatin association inhibits tumor cell growth," Molecular Pharmacology, vol. 81, no. 6, pp. 811-819, 2012.

[32] A. Inoue, S. Kikuchi, A. Hishiki et al., "A small molecule inhibitor of monoubiquitinated proliferating cell nuclear antigen (PCNA) inhibits repair of interstrand DNA cross-link, enhances DNA double strand break, and sensitizes cancer cells to cisplatin," Journal of Biological Chemistry, vol. 289, no. 10, pp. 7109-7120, 2014. 

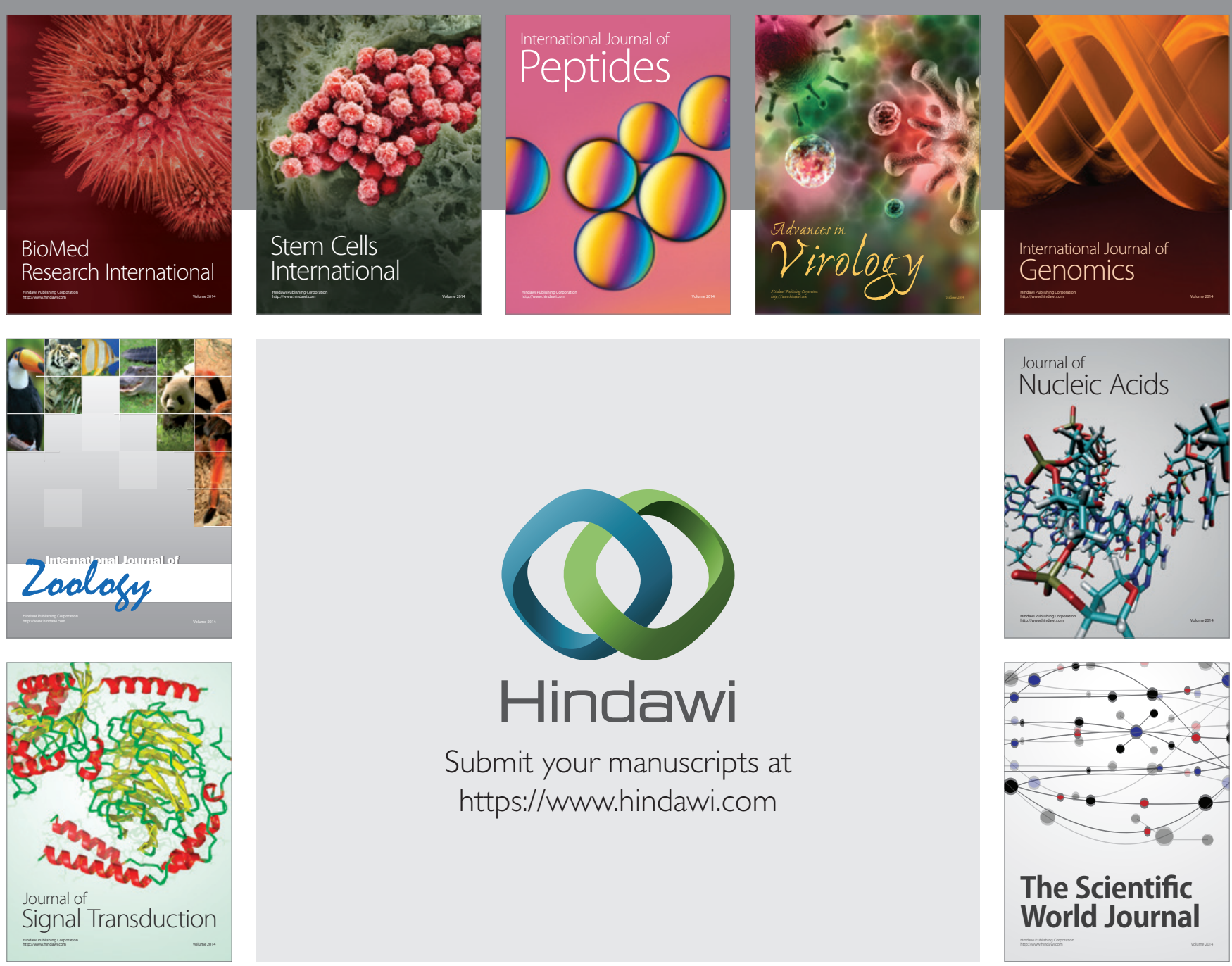

Submit your manuscripts at

https://www.hindawi.com
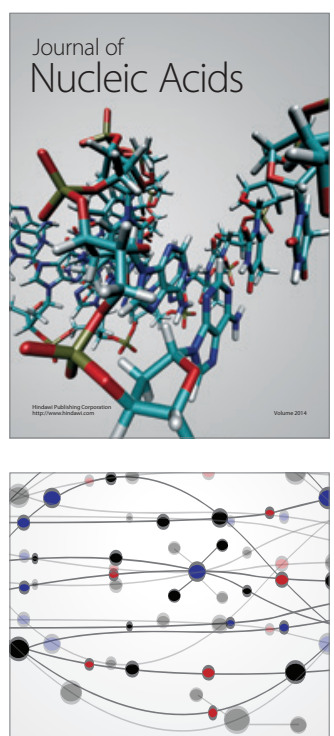

The Scientific World Journal
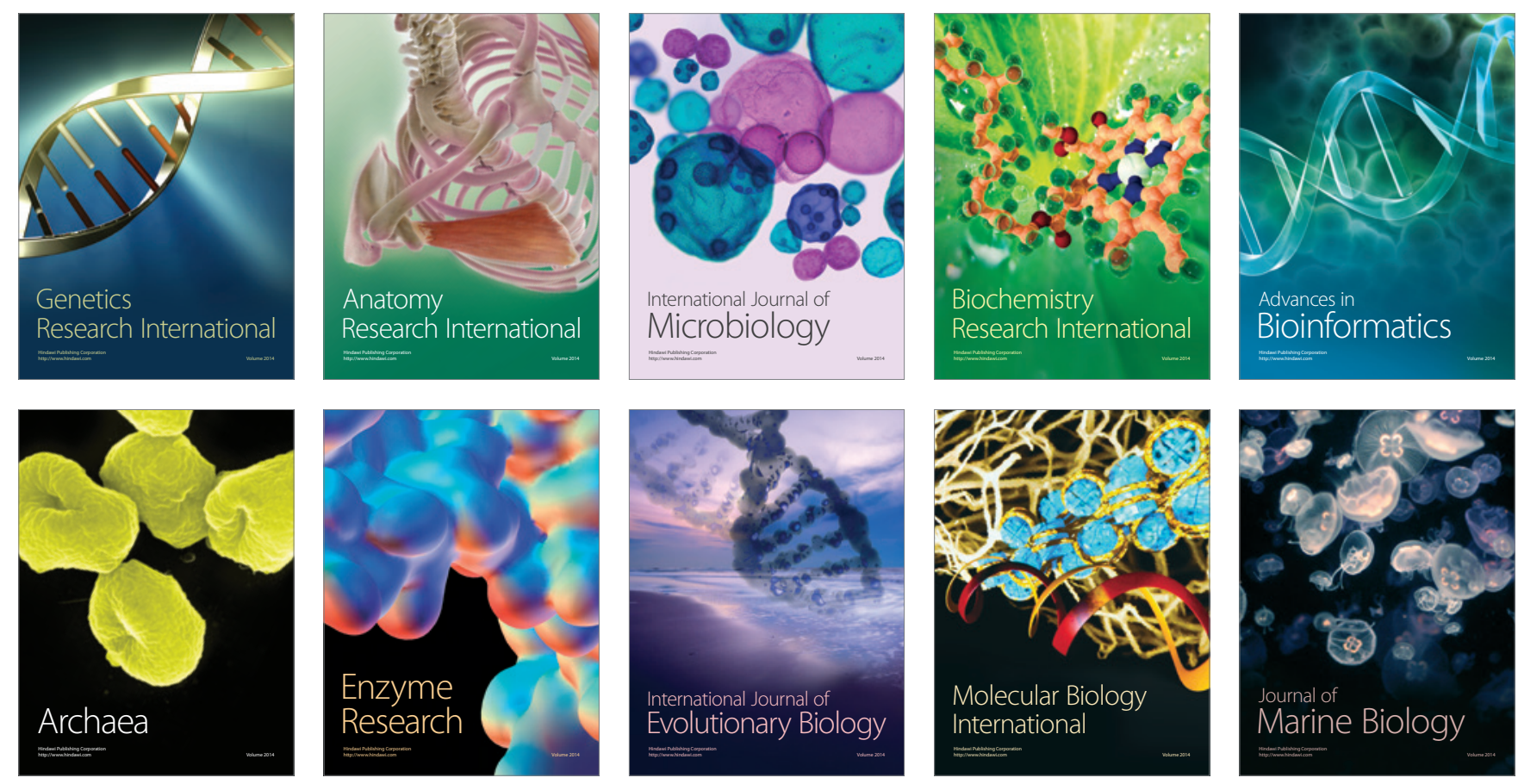